\title{
Growth of 'M9' apple root in five Central Europe replanted soils
}

\author{
Serena Polverigiani ${ }^{1}$, Markus Kelderer ${ }^{2}$ and Davide Neri ${ }^{1}$ \\ ${ }^{1}$ Dipartimento di Scienze Agrarie, Alimentari ed Ambientali, Università Politecnica delle Marche, Via Brecce \\ Bianche 60131 Ancona, Italy \\ ${ }^{2}$ Centro di Sperimentazione Agraria e Forestale Laimburg, Vadena, Ora, BZ, Italy
}

Corresponding author: D. Neri, E-mail: d.neri@univpm.it, Phone: +39 2204431; Fax: +39 2204988

Received on May 7, 2014; Accepted on August 29, 2014

\begin{abstract}
Soil sickness is a widespread problem in replanted apple orchards with a complex symptomatology and etiology influenced by soil and climate conditions. Consequently, a conclusive technical solution is still lacking for intensive apple orchards. The present work aims to analyze the morphological and functional changes occurring in the M9 apple root systems growing in pot filled with soil derived from five different European growing areas. For each growing area, the soil was collected from the apple orchard and used directly in the pot or gamma-ray sterilized before potting. Soil from a neighborhood fallow was also used as control for each growing area. In the non-sterilized replant soils plants developed poor root systems due to a limited biomass allocation. Fibrous roots production was particularly compromised. The roots had a smaller diameter and a lower ramification index. The root cell membrane integrity was also lower. Gamma-ray sterilized replant soils increased root growth, branching and cell integrity, while nearby fallow soil induced an intermediate root behavior. The magnitude of the symptoms showed a significant interaction between soil treatment and sampling site and root growth was correlated with the organic matter content in the soils.
\end{abstract}

Keywords: gamma-ray sterilization, replant disorders, resources partitioning, root efficiency

\section{Introduction}

The replant problem dates from the beginning of agriculture (Columella 70) and the literature refers to the phenomenon in a wide range of species both in annual (Canals et al. 2005) and perennial culture
(Spethmann and Otto 2003, Mai and Abawi 1978). Despite a very ancient knowledge of the problem (Schreiner and Reed 1907) and the dramatic urgency of the topic from an economical point of view, no technical solutions of certain efficacy and sustainability are currently available (Huang et al. 2013). Replant disorders are characterized by a high variability of symptoms as well as by a great unpredictability (Zucconi 2003). Also timing and severity of symptoms expression are highly erratic (Taquair 1984, Yadava and Doud 1980, Mazzola and Manici 2012).

Root is the first plant interface with soil and is the organ that mainly receives stress arising to substrate characteristics. Studies on replant problem in terms of root growth indicated a reduction in root biomass, root tip necrosis (Savory 1966) and a reduction of uptake (Yu and Matsui 1999), causing nutrient deficiencies and plant water stress (Mai et al. 1994, Mazzola and Manici 2012). Recent studies on rootstock tolerance to replant disorders focused on root development in terms of total root biomass (Waschkies et al. 1994, Isutsa and Merwin 2000) while relationships among resource allocation pattern, root function and architecture have often been neglected (Atucha et al. 2014). In response to growth conditions, plants allocated resources toward certain organs preferentially (Polverigiani et al. 2011, Giorgi et al. 2008), leading to the different canopy / root ratio, root architecture and morphology.

In woody plants, roots are often distinguished into two classes, i.e. fibrous (absorptive, short or feeder) and pioneer (framework, long or skeletal) roots. They diverge in both morphology and function (Sutton and Tinus 1983). Resource partitioning patterns tends to reach the maximum efficiency of the root system in response to the various growth conditions (Eissenstat 1992, Eissenstat et al. 2000). When an adverse growth environment causes a stress to the plant and limits

Polverigiani S, Kelderer M, Neri D 2014 Growth of 'M9' apple root in five Central Europe replanted soils. Plant Root 8: 55-63. doi:10.3117/plantroot.8.55

Copyrights 2014, Plant Root (JSRR), www.plantroot.org 
plant productivity, root system showed a phenotypic plasticity, such as modification of root proliferation patterns and its function, possibly as a way of alleviating a detrimental effect of a stress (Sultan 2000). Therefore, parameters such as root diameter or branching frequency are pivotal to understand plant adaptive response to changing growth conditions (Pregitzer et al. 2002).

Histological studies of apple roots in replant soil have reported extensive sloughing of epidermal and cortical tissues, root tip necrosis, and very few functional root hairs in replant soil compared to roots of healthy apple trees under non-replant soil conditions (Caruso et al. 1989, Yim et al. 2013) thus indicating a rapid decline of root functionality and shorter lifespan.

The main objective of this study was to test the following two hypotheses in the short term experiment where root morphological and physiological traits as well as resource portioning patterns to roots were studied in apple rootstock seedlings transplanted in soils with different replant history. We hypothesized that a replant soil would reduce root half-life and the average functional efficiency of the root system, while sterilization would alleviate the short-term stress at transplanting. We also hypothesized that the magnitude of the effect of soil treatment will depend on soil physical and chemical fertility.

\section{Materials and Methods}

\section{Sampling sites and soil analysis}

Soils were sampled in three main apple growing areas of Central Europe: Rhineland Palatinate (Germany), Styria (Austria) and South Tyrol (Italy). Soil samples were collected from orchards on 5 different locations monitored by the following research centers: Fruit Experimental Station Graz-Haidegg in Austria (for the locations Haidegg and Lammer), Centre of Rural Services Rheinpfalz in Germany (KAD and Kramer), and Laimburg Agricultural and Forestry Research Centre in Italy (Leifers). All locations were at the third-generation of replanted orchards. Soil sampling on the 5 orchards was performed in early April 2012 on replant rows and on the fallow controls (driving lanes within the orchards or uncultivated strips at the edge of the orchards) which were managed as permanent natural vegetative cover and had not been directly planted with fruit trees in the past.

Soil texture was classified using the Soil Triangle Hydraulic Properties Calculator based on Saxton et al. (1986). Soil pH and electrical conductivity (EC) were measured with a glass electrode using a $1: 2.5$ soil : $0.01 \mathrm{M} \mathrm{CaCl}_{2}$ (w : v) ratio. Soil dry matter was determined by heating soil for $24 \mathrm{~h}$ at $105^{\circ} \mathrm{C}$. The organic matter content was determined from the weight loss following ignition in a muffle furnace (Carbolite, $\mathrm{CWF} 1000$ ) at $550^{\circ} \mathrm{C}$ for $5 \mathrm{~h}$. Total nitrogen $(\mathrm{N}$ tot) and total carbon $(\mathrm{C}$ tot) in the samples were measured using a TruSpec CHN (Leco Corporation, software version 1.6x,USA). Soil basal respiration was measured as $\mathrm{CO}_{2}$ evolution from moist soil samples at $22^{\circ} \mathrm{C}$, using continuous flow infrared gas analysis (IRGA; Heinemeyer et al., 1989).

\section{Plant material and canopy growth}

Soil samples from all sites were stored at $8^{\circ} \mathrm{C}$, at Laimburg Agriculture and Forestry Research Centre in South Tyrol (Italy) until use for bioassay tests. Soil samples were handled to obtain three soil treatments for each site; they were (i) replanted, (ii) fallow, (iii) gamma-ray sterilized. The gamma ray-sterilization of the replanted soil samples was performed as described in Manici et al. (2013). Replant, sterilized and fallow soils were used as substrate of growth for rooted cuttings of clonal M9 rootstock with diameter of 6-8 mm. Rootstocks were transplanted one per pot $(10 \times 10 \times 15 \mathrm{~cm})$ which was filled with approximately $1.5 \mathrm{~kg}$ of soil. Simulating open field conditions in central Europe, transplant of apple rootstocks was carried out in early June 2012. A two-factorial experiment in a completely randomized block design, with three replicates was performed. Factors were

- soil treatment (3 levels): replanted, sterilized and fallow.

- sampling site (5 levels).

A total of 150 pots (10 replicates with one plantlet per pot, 3 treatments and 5 sites) were arranged in a shade-house at the Laimburg Agriculture and Forestry Research Centre (Italy). Total shoot length $(\mathrm{cm})$ and dry matter $(\mathrm{g})$ of the canopy, including shoot and stem, were measured 85 days after planting.

\section{Root biomass and morphology}

Four replicates for each soil treatment of the different locations were used for root description, for a total of 60 plants, 85 days after planting. Roots were extracted from the pot and gently washed free of soil. Roots were washed over a $0.3 \mathrm{~mm}$ mesh sieve in order to collect all excised fragments. The whole root system was separated, depending on root hierarchical position, into five orders according to Fitter (1991), by dividing single orders from 1 st to 4 th and by combining all structures of order 5 th and higher as "> 4th order". The root diameter was used as the 
discriminant on root fragments only when the original architecture was disrupted, and thus not recognizable. The 1st and 2 nd order roots, pooled together, represented the fibrous fraction of the root system (root diameter $0.26 \pm 0.02 \mathrm{~mm}$ ). Root from 3rd order to higher represented the pioneer portion (Polverigiani et al. 2011). Pioneer and fibrous root fractions were dried and weighted separately. Root biomass (dw) was used to calculate the percentage of fibrous roots out of the whole root system. For root morphological characterization, only living, intact and healthy roots were considered for analysis, whereas all the damaged, shrunken or partially decomposed roots were discarded. Morphological parameters were measured just on pioneer structures, separately for each of the three orders. The diameter, length, number of laterals and dry weight of a sub-sample of 15 roots per order were measured for each plant. When 15 roots were not available for the measurement of $>4$ th order class, all the roots were measured. When the number of available roots exceeded the 15 units, the subsample was composed by randomly selected roots. The root length and diameter were measured by processing images of the root samples through the DigiRoot ${ }^{\mathrm{TM}}$ software (Digital Processing Solutions LLC, CO, USA) for image analysis. The root length and dry weight were used to estimate the amount of root length per unit biomass or "specific root length" (SRL). The lateral branching rate was calculated on the same root samples, as the number of laterals produced per unit length.

\section{Root cell damage}

As an indicator of stress (Huang et al. 2005), root electrolyte leakage was used to assess cell membrane stability and integrity as described in Martin et al. (1987). On each of the four replicates, 5 sub-samples of fibrous roots were collected and analysed. The subsamples consisted of on average $10 \mathrm{mg}(\mathrm{dw})$ of 1st and 2nd order roots. Roots were cleaned from soil residues and immersed in deionized water. Electrical conductivity (EC) of the water was measured before roots were inserted $\left(\mathrm{EC}_{\text {initial }}\right)$, after $30 \mathrm{~min}$ of immersion $\left(\mathrm{EC}_{30}\right)$, and again after boiling the sample for 5 $\min \left(\mathrm{EC}_{\text {total }}\right)$. Electrolyte leakage was calculated using the following relationship:

Electrolyte leakage $(\%)=100 \times\left(\mathrm{EC}_{30}-\mathrm{EC}_{\text {initial }}\right) /$ $\left(\mathrm{EC}_{\text {total }}-\mathrm{EC}_{\text {initial }}\right)$.

\section{Statistical analysis}

All data were tested using a two-way ANOVA focusing on the influence of soil replant status, sampling site and their cross interaction. For parame- ters measured on single root order (i.e. diameter, SRL, branching frequency) the ANOVA and all subsequent statistical elaborations were performed on each order separately. When the ANOVA indicated significant treatment effect, a Tukey's HSD test, at 95\% confidence level, was performed for mean separation. A Principal Component Analysis (PCA) was performed using the whole data sets of root parameters. Statistical analysis was performed using JMP9 (SAS Institute Inc., Cary, NC).

\section{Results}

\section{Biomass partitioning}

Canopy growth differed among treatments; shoot length and canopy dry matter were significantly higher in gamma-ray sterilized soil than in replant soil (data not shown), as illustrated in Manici et al. (2013). Plant root growth was strongly influenced by soil treatment. The gamma-ray sterilized soil and neighborhood fallow soil showed a greater root weight compared to replant treatment. The weakly significant interaction at $P=0.10$ between treatment and site indicates a different effect of soil treatment depending on site (Table 1). Namely, only two out of the five sites showed significant differences on root growth due to soil treatment (Fig. 1). On both cases gamma-ray sterilized soil promoted a higher root growth compared to replant soil. Root growth on fallow soil was significantly higher than in replant treatment only in KAD (Fig. 1). Both the sampling sites and the soil treatments played a role in determining the canopy / root ratio (Table 1). In replant soil, roots showed a disproportionate decreases relative to canopy, thus increasing the ratio of canopy to root dry weight as compared with gamma-irradiated soil (Table 1). A more detailed analysis focusing on biomass partitioning among the root system showed that the replant soil condition particularly reduced the fibrous root fraction compared to the pioneer fraction. Thus the fibrous root proportion expressed as percentage of total root dry weight was significantly lower (Table 1).

\section{Root morphology and architecture}

Root diameter, SRL and branching frequency differed among orders, treatments and sites (Table 2). Significant interactions between sampling sites and treatments were found for root diameter and branching frequency, while significant interaction between order and treatment was found only for root diameter. For SRL, however, weak interactions between site and treatment and between order and treatment were found. Thus, root diameter was significantly higher in sterilized than in replant and fallow soil in $>4$ th order 
Table 1. Two-way ANOVA and means separation test of root growth parameters: M9 rootstock plantlet root dry weight, canopy / root, the percentage of fibrous roots out of the whole root system (dry weight basis), at 85 days after planting. Values with different letter are significantly different according to Tukey's HSD mean separation test $(P$ $<0.05)$.

\begin{tabular}{lcccc}
\hline & DF & Root dry weight $^{\mathrm{a}}$ & ${\text { Canopy } / \text { root }^{\mathrm{a}}}$ & Root mass that was fibrous $^{\mathrm{a}}$ \\
\hline Site & 4 & 0.021 & $<.0001$ & $<.0001$ \\
Treatment & 2 & 0.0001 & 0.007 & $<.0001$ \\
Site $\times$ Treatment & 8 & 0.10 & 0.002 & $<.0001$ \\
& & & \\
Treatment & Count & Root dry weight $(\mathrm{g})$ & Canopy / root & Root mass that was fibrous (\%) \\
\hline Replanted & 20 & $1.15 \pm 0.11 \mathrm{~b}$ & $8.05 \pm 0.91 \mathrm{a}$ & $53.1 \pm 1.18 \mathrm{~b}$ \\
Fallow & 20 & $1.66 \pm 0.17 \mathrm{a}$ & $5.99 \pm 0.84 \mathrm{ab}$ & $55.2 \pm 1.38 \mathrm{~b}$ \\
Sterilized & 20 & $1.91 \pm 0.12 \mathrm{a}$ & $5.25 \pm 0.34 \mathrm{~b}$ & $60.0 \pm 1.43 \mathrm{a}$ \\
\hline
\end{tabular}

${ }^{a}$ Numbers in the Table represent the probability values

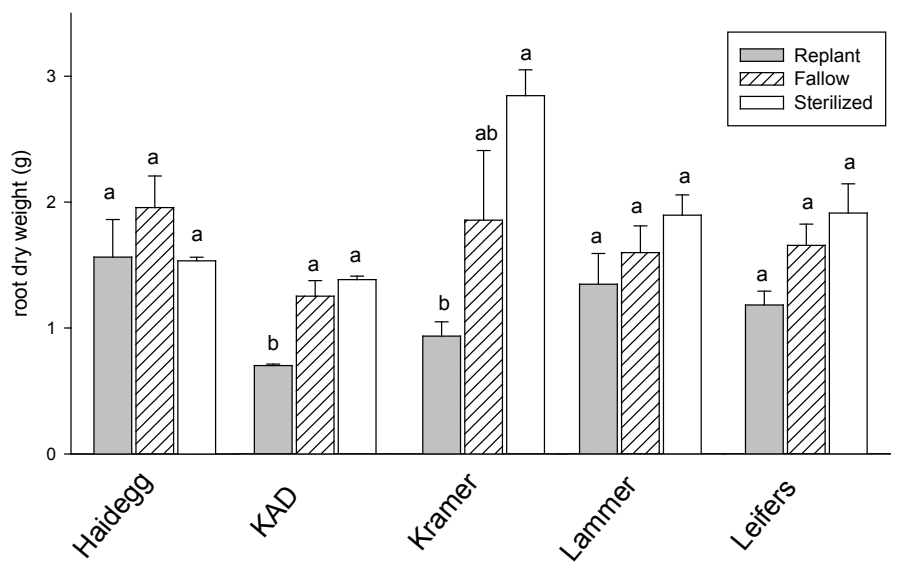

Fig. 1. Mean separation test for root dry weight of M9 rootstock grown on replant, fallow and sterilized soil samples, from 5 sites. Each data represents the average of four replicates. Vertical bars indicate mean \pm standard error. Means with different letter significantly differ according to Tukey's HSD test $(P<0.05)$.

and SRL was greater in replant than in fallow and sterilized soils in 4th order (Fig. 2). On the other hand, branching frequency was lower in replant than in sterilized and fallow soils for the 3rd, 4th and $>4$ th order structures (Table 2 and Fig. 2).

\section{Root cell damage}

The level of cell membrane damage differed among soil treatments and sites. The magnitude of the effect of soil treatment was not uniform among sites as indicated by the significant soil treatment $\times$ site interaction $(P=0.044)$ (Table 3$)$. The replant soil increased the level of cell damage compared to fallow soil on two locations i.e., KAD and Kramer. Replant soil significantly increased electrolyte leakage than gamma-ray sterilized soil only in one location, Kramer (Fig. 3).

\section{Response magnitude and soil characteristics}

The replant soil generally influenced root characteristics by reducing root vigour and branching rate. The Principle Component Analysis indicated that the eigenvalues were $3.73,1.57,1.29$ and 0.63 for the first 4 components, respectively, and suggested the adoption of three principle components. These three components accounted for 46.6, 19.6 and $16.2 \%$ of total variability respectively. However since the third component was strongly dominated by the single variable 'diameter' and therefore was not effective in improving the clarity of the description, only the first two components were taken into account in this study. The first principle component was related to root vigour (total weight of roots, fibrous root weight, SRL and leakage), while the second component was mostly related to branching frequency and proliferation in the niches (percentage of fibrous roots out of the whole 
Table 2. Two-way ANOVA of root morphological parameters: M9 rootstock plantlet root diameter, SRL and branching frequency, 85 days after planting. Analysis was performed on 15 roots for each root order per replicate

\begin{tabular}{lcccc}
\hline & DF & Root diameter $^{\mathrm{a}}$ & Specific root length $^{\mathrm{a}}$ & Branching frequency $^{\mathrm{a}}$ \\
\hline Site & 4 & $<.0001$ & 0.020 & $<.0001$ \\
Treatment & 2 & $<.0001$ & 0.024. & $<.0001$ \\
Order & 2 & $<.0001$ & $<.0001$ & 0.036 \\
Site $\times$ Treatment & 8 & $<.0001$ & 0.077 & $<.0001$ \\
Order $\times$ Treatment & 4 & $<.0001$ & 0.059 & 0.340 \\
\hline
\end{tabular}

${ }^{\mathrm{a}}$ Numbers in the Table represent the probability values

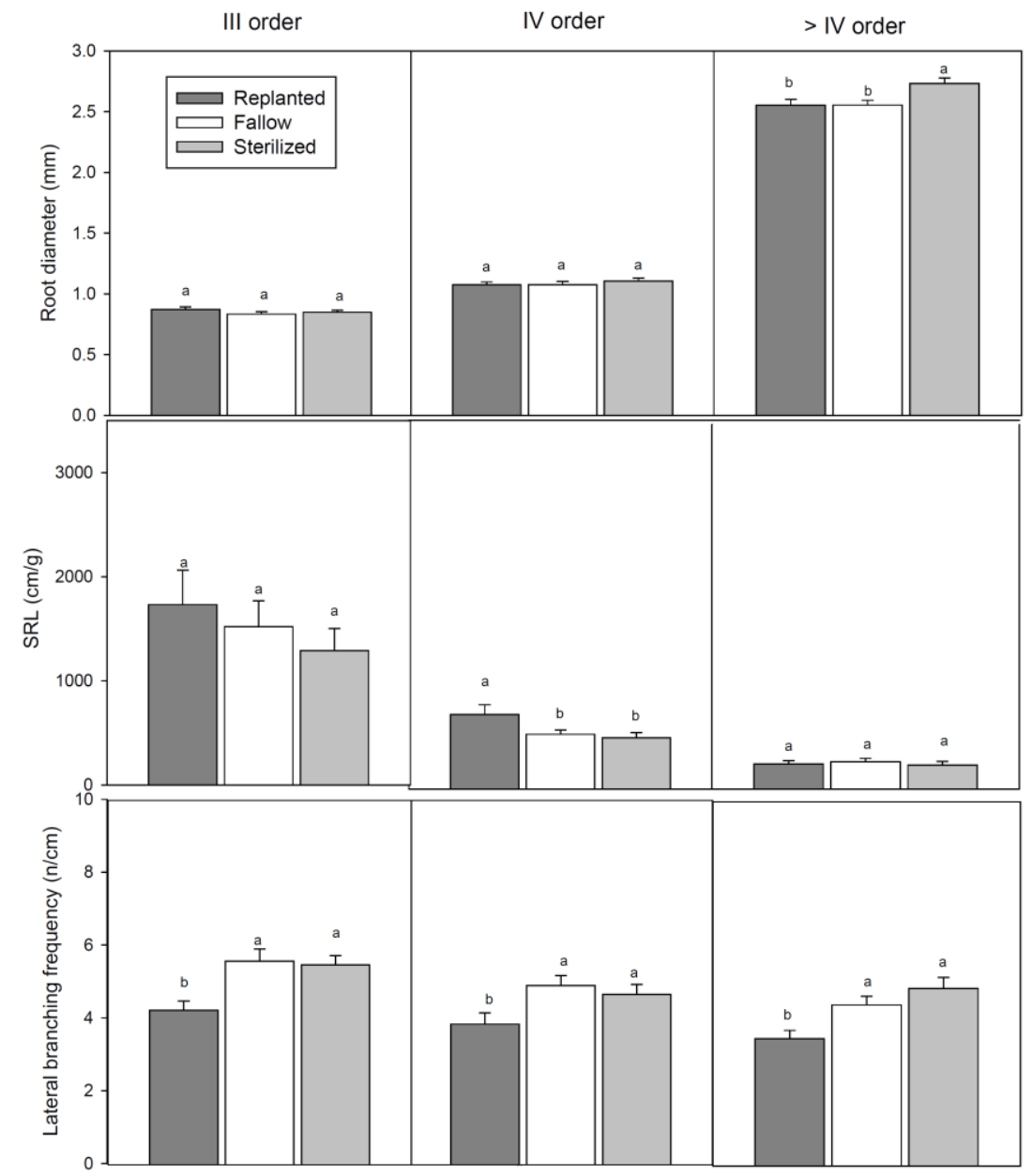

Fig. 2. Means separation test for root diameter, SRL and lateral branching frequency of each of the three pioneer root classes. Vertical bars indicate mean \pm standard error. Means with different letter significantly differ according to Tukey's HSD tests $(P<0.05)$. root system, root branching frequency). The PCA scores confirmed how replant soil mostly differed from the other two treatments and indicated a non-uniform magnitude of the effect of replant treatment among sites; i.e., KAD and Kramer showed a wider distance of fallow and sterilized soil from the replant (Fig. 4).

Soil chemical and biochemical parameters, as expected, varied between sites (Table 4). The site KAD showed the lower level of $\mathrm{N}_{\text {tot }}$ as well as the lowest organic matter $(\mathrm{OM})$ content $(\%)$. KAD and Kramer were also characterized by the lowest basal respiration. Haidegg had the most balanced soil texture and the highest values $\mathrm{N}_{\text {tot }}, \mathrm{C}_{\text {org }}$ and OM. In replant soil root growth was strongly and positively correlated with soil total $\mathrm{N}_{\text {tot }}(r=0.87)$ and OM content $(r=0.96)$ but correlations were not significant for gamma-ray sterilized or fallow soil. 


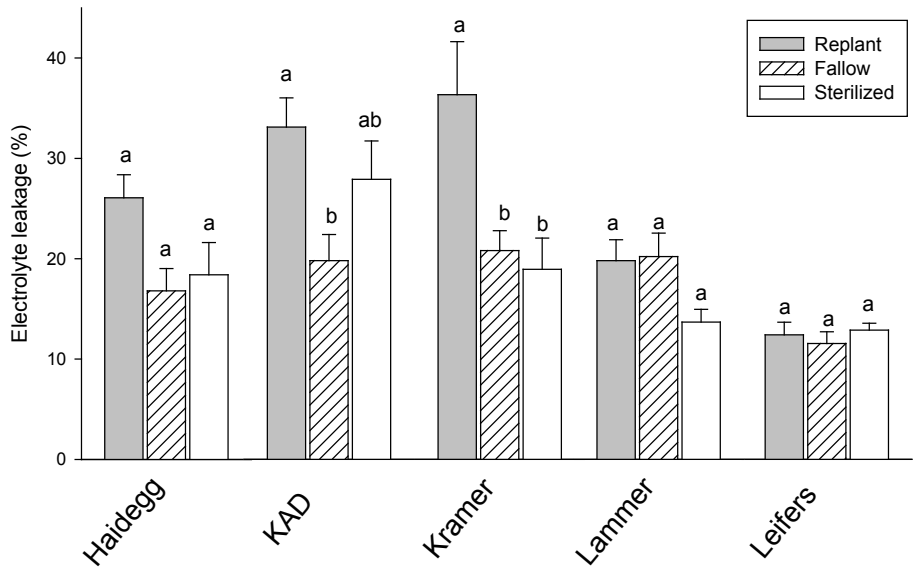

Fig. 3. Means separation test for root electrolyte leakage of M9 rootstock on soil samples coming from replant, fallow and sterilized soil samples, from 5 sites. Each data represents the average of five roots for each of the four replicates (20 root samples in total). Vertical bars indicate mean \pm standard error. Means with different letter significantly differ according to Tukey's HSD tests $(P<0.05)$.
Table 3. Two-way ANOVA of root electrolyte leakage 85 days after planting. Analysis was performed on 5 root sub-samples per replicate

\begin{tabular}{llc}
\hline & DF & Electrolyte leakage $^{\mathrm{a}}$ \\
\hline Site & 4 & $<.0001$ \\
Treatment & 2 & $<.0001$ \\
Site $\times$ Treatment & 8 & 0.044 \\
\hline
\end{tabular}

${ }^{\mathrm{a}}$ Numbers in the Table represent the probability values

\section{Discussion and Conclusion}

The short term trial indicated a general reduction of biomass allocation to root after planting of apple M9 cuttings in replant soils. The biomass allocation to root decreased more than proportionally compared to the reduction of the above-ground part and caused an elevated canopy / root ratio as typical response for plants exposed to root stress (Wilson 1988). The detail analysis on single root hierarchical order indicated the production of thinner root in replant soil, judging from the smaller diameter of the $>4$ th order roots and the higher SRL of the 4th order roots in replant soil (Fig. 2) This contributed to the reduction of resource allocation to the root system as previously found by Atucha et al. (2014) in similar conditions.

Replant soil caused a reduction of the branching frequency regardless of root order (Table 2) and a disproportionately large reduction of fibrous roots compared to the pioneer root fraction (Table 1). These behaviours can be assumed as a lower tendency to colonize the soil and an impairment of the absorbing ability of root (Zadworny and Eissenstat 2011). Root tended to grow in the search of new niches preferentially instead of localized proliferation under environmental conditions unfavourable for resource uptake (Polverigiani et al. 2011, Polverigiani et al. 2014), and this tendency can be assumed as an indicator for a resource limited condition (Giorgi et al 2008).

The restricted growth in replant soil could be ascribed to the accumulation of self-produced residues, which induced specific allelopathic effects (dispathy) under repeated cultivation conditions. In previous studies root absorbing ability was hindered by toxins from previous crop residues, leading to the dystrophies and root die-back (Neri 2013; Giorgi et al 2008; Neri et al 2005). In the present study, roots grown in replant soil showed the highest electrolyte leakage in comparison with root grown in fallow or gamma-sterilised soil (Fig. 3). This result is potentially connected to a lower root lifespan in replant soils as previously found by Bauerle et al (2008) and is related to higher level of cell membrane disruption. Reduced proliferation pattern and faster root shedding can be interpreted as avoidance response to unfavourable conditions which temporarily reduced soil exploration and resource uptake by roots. In addition, soil sickness enhances the risk of infection by soil borne pathogens through an indirect biochemical and physiological effect (Ye et al. 2006). However, the associations among the accumulation of toxins, root functional activity and risk of infection remains a complex issue to be further examined.

In this study, the plants in replant soil lost their cell membrane integrity in KAD and Kramer, but not in Haidegg, Lammer and Leifers (Fig. 3). This suggests that plant survival and activity was less dramatically jeopardized in replant soils with high organic matter 

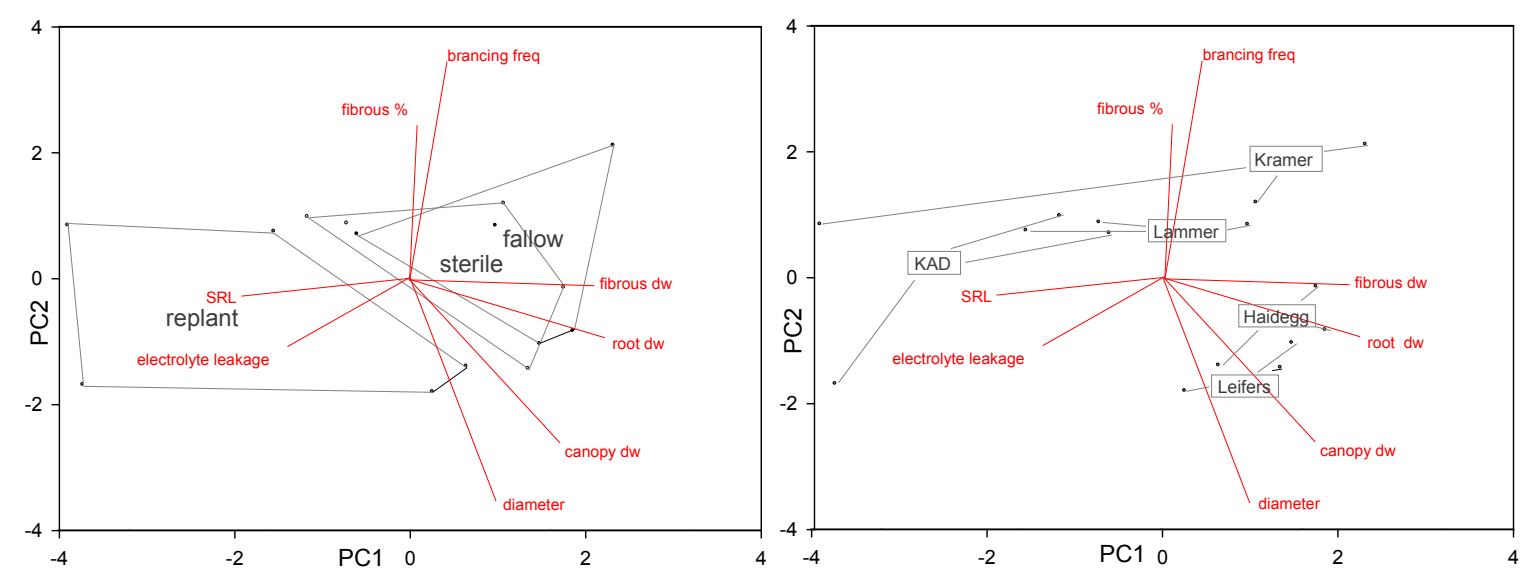

Fig. 4. PCA of all measured root parameters in response to soil replant treatment and sites. The PCA resumes the 8 variables: canopy $\mathrm{dw}$, total root $\mathrm{dw}$, fibrous $\mathrm{dw}$, percentage of fibrous roots out of the whole root system, root diameter, SRL, root branching frequency and electrolyte leakage on two principal components. Each point represents the average of the four replicates for each treatment on each site.

Table 4. Physical, chemical and biological properties of soils

\begin{tabular}{|c|c|c|c|c|c|c|c|c|c|c|}
\hline Country & Site & $\begin{array}{c}\text { Soil } \\
\text { treatment }\end{array}$ & $\begin{array}{c}\text { Soil } \\
\text { texture }\end{array}$ & $\mathrm{pH}$ & $\begin{array}{l}\mathrm{N}_{\text {tot }}^{\mathrm{a}} \\
(\%)\end{array}$ & $\begin{array}{c}\mathrm{C}_{\text {org }} \\
(\mathrm{mg} / \mathrm{g})\end{array}$ & $\begin{array}{l}\mathrm{DM} \\
(\%)\end{array}$ & $\begin{array}{c}\mathrm{OM} \\
(\mathrm{mg} / \mathrm{g})\end{array}$ & $\begin{array}{l}\text { Conduct } \\
(\mu \mathrm{S} / \mathrm{cm})\end{array}$ & $\begin{array}{c}\mathrm{BR} \\
\left(\mu \mathrm{gTS}^{-1} \mathrm{~h}^{-1}\right)\end{array}$ \\
\hline \multirow[t]{2}{*}{$\mathrm{AT}$} & HAIDEGG & Replant & s.c.l. ${ }^{b}$ & 5.78 & 0.35 & 47.53 & 75.86 & 81.75 & 138.5 & 0.586 \\
\hline & HAIDEGG & Fallow & s.c.l. & 5.36 & 0.42 & 51.08 & 73.76 & 87.85 & 142.2 & 1.822 \\
\hline \multirow[t]{2}{*}{ AT } & LAMMER & Replant & s.l. & 6.88 & 0.21 & 40.36 & 74.35 & 69.42 & 217.2 & 1.692 \\
\hline & LAMMER & Fallow & s.l. & 5.86 & 0.17 & 37.30 & 73.41 & 64.15 & 113.0 & 1.191 \\
\hline \multirow[t]{2}{*}{ IT } & LEIFERS & Replant & s.l. & 7.74 & 0.25 & 32.92 & 73.58 & 56.63 & 116.3 & 2.290 \\
\hline & LEIFERS & Fallow & s.l. & 7.76 & 0.21 & 28.36 & 73.84 & 48.78 & 129.7 & 2.341 \\
\hline \multirow[t]{2}{*}{$\mathrm{DE}$} & KAD & Replant & s.l. & 6.80 & 0.14 & 26.65 & 87.04 & 45.84 & 101.2 & 0.426 \\
\hline & KAD & Fallow & s.1. & 7.36 & 0.11 & 17.15 & 88.88 & 29.50 & 71.0 & 0.137 \\
\hline \multirow[t]{2}{*}{$\mathrm{DE}$} & KRAMER & Replant & c.l. & 6.60 & 0.21 & 30.35 & 83.57 & 52.20 & 59.0 & 0.747 \\
\hline & KRAMER & Fallow & c.l. & 6.52 & 0.19 & 27.72 & 85.54 & 47.68 & 51.7 & 0.045 \\
\hline
\end{tabular}

${ }^{\mathrm{a}} \mathrm{N}_{\text {tot }}$ (total nitrogen) ; $\mathrm{C}_{\text {org }}$ (organic carbon); DM (dry matter); OM (organic matter); Conduct. (conductivity); BR (basal respiration).

${ }^{\mathrm{b}}$ Sandy (s.), clay (c.), loam (1.).

content and better chemical and physical fertility. All agronomic practices should be focused on promoting plant adaptive response. Some edaphic conditions are able to reduce root cell damage, thus increasing plant resilience and tolerance to biotic stress. Elevated organic matter content or a proper soil structure are effective in maintaining the highest proliferation rate of roots. All agronomical interventions aiming to create the most suitable environment for root activity and proliferation has to be studied as a tool in preventing the replant symptomatology.
The present work highlights some characteristics of the growth environment that might magnify the expression of the soil sickness symptomatology. The most unfavourable soil texture and the presence of the lowest concentration of $\mathrm{OM}, \mathrm{N}$ and soil basal respiration caused the highest stress in replant soil. In conclusion, our work suggests that a proper soil physical, chemical and biological fertility is able to minimize the negative effects of replant disorders on root proliferation and functionality. 


\section{Acknowledgments}

The authors acknowledge the financial support for BIO-INCROP project provided by the CORE Organic II Funding Bodies, being partners of the FP7 ERA-Net project no. 249667 Coordination of European Transnational Research in Organic Food and Farming systems www.coreorganic2.org, and Thomas Rühmer from Versuchsstation Obst- und Weinbau Haidegg, Gerhard Baab from DLR Rheinpfalz, Luisa Manici from CRA-CIN and Anne Topp from Centro di Sperimentazione Agraria e Forestale Laimburg.

\section{References}

Atucha A, Emmett B, Bauerle TL 2014 Growth rate of fine root systems influences rootstock tolerance to replant disease. Plant Soil 376: 337-346.

Bauerle TL, Richards JH, Smart DR, Eissenstat DM 2008 Importance of internal hydraulic redistribution for prolonging the lifespan of roots in dry soil. Plant Cell Environ. 31: 177-186.

Canals RM, Emeterio LS, Peralta J 2005 Autotoxicity in Lolium rigidum: Analyzing the role of chemically mediated interactions in annual plant populations. J. Theor. Biol. 235: 402- 407.

Caruso FL, Neubauer BF, Begin MD 1989 A histological study of apple roots affected by replant disease. Can. J. Bot. 67: 742-749.

Columella LGM 70 De re rustica (On Agriculture) Vol.I, Loeb Classical Library No. 361. Harvard University Press.

Eissenstat DM 1992 Costs and benefits of constructing roots of small diameter. J. Plant Nutr. 15:763-782.

Eissenstat DM, Wells CE, Yanai RD, Whitbeck JL 2000 Building roots in a changing environment: Implications for root longevity. New Phytol. 147: 33 - 42.

Fitter AH 1991 Characteristics and functions of root systems. In Waisel Y, Eshel A, Kafkafi Y, eds., Plant roots: The hidden half. Marcel Dekker, New York, pp. 3-25.

Giorgi V, Neri D, Lodolini EM, Savini G 2008 Olea europaea L. root growth in soil patches with olive husks and hay residues. Int. J. Fruit Sci. 7: 19-32.

Heinemeyer O, Insam H, Kaiser EA, Walenzik G 1989 Soil microbial biomass measurements: an automated technique based on infrared analysis. Plant Soil 116: 191-195.

Huang LF, Song LX, Xia XJ, Mao WH, Shi K, Zhou YH, Yu JQ 2013 Plant-soil feedbacks and soil sickness: from mechanisms to application in agriculture. J. Chem. Ecol. 39: 232-242.

Huang X, Lakso AN, Eissenstat DM 2005 Interactive effects of soil temperature and moisture on Concord grape root respiration. J. Exp. Bot. 56: 2651-2660.

Isutsa DK, Merwin IA 2000 Malus germplasm varies in resistance or tolerance to apple replant disease in a mixture of New York orchard soils. HortSci. 35:262-268.

Mai WF, Abawi GS 1978 Determining the cause and extent of apple, cherry and pear replant diseases under controlled conditions. Phytopathol. 68: 1540-1544.

Mai WF, Merwin IA, Abawi GS 1994 Diagnosis, etiology, and management of replant problems in New York cherry and apple orchards. Acta Hort. 363: 33-41.

Manici LM, Kelderer M, Franke-Whittle IH, Rühmer T, Baab G, Nicoletti F, Caputo F, Topp A, Insam H, Naef A 2013
Relationship between root-endophytic microbial communities and replant disease in specialized apple growing areas in Europe. Appl. Soil Ecol. 72: 207-214.

Martin U, Pallardy SG, Bahari ZA 1987 Dehydratation tolerance of leaf tissue of six woody angiosperm species. Physiol. Plant. 669: 182-186.

Mazzola M, Manici LM 2012 Apple replant disease: role of microbial ecology in cause and control. Annu. Rev. Phytopathol. 50: 45-65.

Neri D, Sugiyama N, Inujima A 2005 Effects of organic residues on strawberry root growth. Int. J. Fruit Sci. 1: 127-139.

Neri D 2013 Organic soil management to prevent soil sickness during integrated fruit production. Integrated protection of fruit crops. In: Ioriatti C, Altindisli FÖ, Børve J, Escudero-Colomer L, Lucchi A, Molinari F eds., IOBC-WPRS Bulletin Vol. 91, ISBN 978-92-9067-269-2 [XIV + 558 pp.], International Organisation for Biological and Integrated Control, pp. 87-99.

Polverigiani S, McCormack ML, Mueller CW, Eissenstat DM 2011 Growth and physiology of olive pioneer and fibrous roots exposed to soil moisture deficits. Tree Physiol. 31: 1228-1237.

Polverigiani S, Kelderer M, Lardschneider E, Neri D 2014 Organic wastes use in horticulture: influences on nutrient supply and apple tree growth. Int. J. Plant Soil Sci. 3: 358-371.

Pregitzer KS, DeForest JL, Burton AJ, Allen MF, Ruess RW, Hendrick RL 2002 Fine root architecture of nine north American trees. Ecol. Monogr. 72: 293-309.

Savory BM 1966 Specific replant diseases causing root necrosis and growth depression in perennial fruit and plantation crops. Research Review No. 1. Commonw. Bur. Hortic. and Plantation Crops, East Malling, Maidstone, Kent, England.

Saxton KE, Rawls WJ, Romberger JS, Papendick RI 1986 Estimating generalized soil water characteristics from texture. Soil Sci. Soc. Amer. J. 50: 1031-1036.

Schreiner O, Reed HS 1907 The production of deleterious excretions by roots. Bull. Torrey Bot. Club. 34: 279-303.

Spethmann W, Otto G 2003 Replant problems and soil sickness. In: Roberts AV, Debener T and Gudin S eds., Encyclopedia of rosescience. Elsevier Ltd., pp. 169-180.

Sultan SE 2000 Phenotypic plasticity for plant development, function and life history. Trends Plant Sci. 5: 537-542.

Sutton RF, Tinus RW 1983 Root and root system terminology. For. Sci. Monogr. 24.

Taquair JA 1984 Etiology and control of orchard replant problems: a review. Can. J. Plant Pathol. 6: 54-62.

Wilson JB 1988 A review of evidence on the control of shoot: root ratio, in relation to models. Ann. Bot. 61: 433-449.

Waschkies C, Schropp A, Marschner H 1994 Relations between grapevine replant disease and root colonization of grapevine (Vitis sp.) by fluorescent pseudomonads and endomycorrhizal fungi. Plant Soil 162: 219-227.

Ye SF, Zhou YH, Suna Y, Zou LY, Yu JQ 2006 Cinnamic acid causes oxidative stress in cucumber roots, and promotes incidence of Fusarium wilt. Environ. Exp. Bot. 56: 255-262.

Yim B, Smalla K, Winkelmann T 2013 Evaluation of apple replant problems based on different soil disinfection treatments-links to soil microbial community structure? Plant Soil 366: 617-631.

Yu JQ, Matsui Y 1999 Autointoxication of root exudates in Pisum sativus. Acta Hort. Sinica 26: 175-179

Yadava UL, Doud SL 1980 The short life and replant 
problems of deciduous fruit trees. Hort. Rev. 2: 1-116.

Zadworny M, Eissenstat DM 2011 Contrasting the morphology, anatomy and fungal colonization of new pioneer and fibrous roots. New Phytol. 190: 213-221.

Zucconi F 2003 Declino del suolo e stanchezza del terreno (Soil decline and soil sickness). Pitagora (ed) Bologna, Italy.

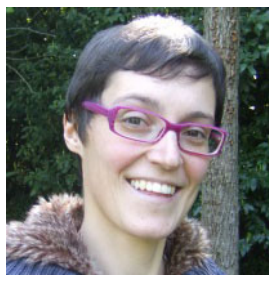

Dr.Serena Polverigiani focuses her research on the effect of management techniques and soil fertility on fruit trees and crop root architecture, growth, metabolism and survivorship.

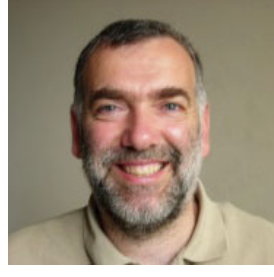

Prof. Davide Neri is studying the sustainability of fruit production focusing on the need for diversity and integration of different cultural approaches. He studied the response of the root system of several fruit species to mono specific and mixed organic residues simulating different replant conditions.

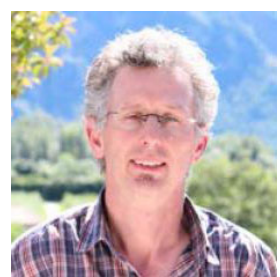

Dr. Markus Kelderer focuses his research activities on praxis oriented experimental work and consultancy in organic fruit and wine growing with special attention to variety evaluation, crop regulation, growing systems, fertilization, plant protection, irrigation and post harvest. 